\title{
Allelopathic Effect of Cyperus rotundus L. on Seed Germination and Initial Growth of Glycine max L. cv. Grobogan*
}

\author{
Sri Darmanti ${ }^{1}$, Santosa $^{2}$, Kumala Dewi ${ }^{2}$ and L. Hartanto Nugroho ${ }^{2}$ \\ 1) Departement of Biology, Faculty of Science and Matemathic, Diponegoro University, Semarang, Indonesia. \\ Email: darmantisri@yahoo.co.id \\ 2) Faculty of Biology, Gadjah Mada University, Yogyakarta, Indonesia \\ *) This article already presented in $3^{\text {nd }}$ Annual Basic Science International Conference 2013.
}

\begin{abstract}
Allelopathy is a phenomenon of direct or indirect, beneficial or adverse effects of a plant on its own or another plant through the release of chemicals into the environment. This experiment was carried out to determine the allelopathic effect of Cyperus rotundus L. (purple nutsedge) tuber aqueous extract on seed germination and initial growth of Glycine max L. (soybean) seedlings. The experiment was performed in completely randomized (CRD) design with five replications, using a range of concentrations of aqueous tuber extracts of nutsedge, i.e.: $0 \%$, $5 \%, 10 \%, 15 \%, 20 \%$ and $25 \%$. The petri dish experiment showed that with increase of the tuber extract concentration, a significant increase was noted in mean germination time (MGT), significant decreases in germination index (GI), growth tolerance index (GTI), wet weight seedling, dry weight seedling and length of soybean seedling.
\end{abstract}

Key words : allelopathy, aqueous extracts, germination, Cyperus rotundus L., Glycine max L.

\begin{abstract}
Abstrak
Alelopati adalah fenomena pengaruh langsung maupun tidak langsung, menguntungkan maupun merugikan terhadap tanaman sendiri atau tanaman yang lain melalui pelepasan bahan kimia ke lingkungan. Penelitian bertujuan untuk mengetahui pengaruh alelopati ekstrak air umbi teki (Cyperus rotundus L.) terhadap perkecambahan benih dan pertumbuhan awal kecambah kedelai (Glycine max L. cv. Grobogan). Disain penelitian rancangan acak lengkap (RAL) dengan lima ulangan, menggunakan berbagai konsentrasi ekstrak air umbi teki, yaitu: 0\%, 5\%, 10\%, $15 \%, 20 \%$ dan 25\%. Percobaan pada cawan petri menunjukkan bahwa dengan meningkatnya konsentrasi ekstrak umbi, menyebabkan peningkatan waktu perkecambahan (MGT), penurunan indeks perkecambahan (GI), indeks toleransi pertumbuhan (GTI), berat basah kecambah, berat kering kecambah dan panjang kecambah kedelai.
\end{abstract}

Kata kunci : alelopati, ekstrak air, perkecambahan, Cyperus rotundus L., Glycine max L. cv. Grobogan.

\section{INTRODUCTION}

Soybean (Glycine $\max$ L.) is one of the principal legume commodities in Indonesia and globally. Soybean cv. Grobogan, a local soybean cultivar from Grobogan district, Central Java province, Indonesia. However, to date, soybean production and productivity in Indonesia have been relatively low (Anonymous, 2012). One of the most important biotic factors which has been a constraint to increasing production of soybeans has been the incomplete weeding out of common competitors, to the point where this has caused heavy competition between soybean crops and particular weeds (Partohardjono, 2005; Atman, 2006; Anonymous, 2009). Purple nutsedge (Cyperus rotundus $\mathrm{L}$.) is one of the most important and dominant of the weeds affecting soybean plantations in Indonesia, and has become a serious agricultural problem, due to the decrease in yields it has caused. In some soybean cropping areas, the loss in yield caused by this one weed is estimated as running from 23 to $89 \%$ (Anonymous, 2009; Kavitha et al.,2012).

A weed is a plant out of place not intentionally sown, whose undesirable qualities outweigh its good points, and its character is 
normally highly consumptive of growth factors; competitive, and invasive (Kohli et al., 2006). Its influence causes immediate losses to the plantation crop through allelopathy and through competition for water, nutrients and light, causing limitations in availability of the latter to the plantation crop (Qasem \& Foy, 2001; Marvollo et al., 2011; Junaedi dkk., 2006). This competition leads to a decrease in the availability of water in the soil (ratnayaka et al., 2003), simultaneously with the synthesis and accumulation of allelochemicals stimulated by competition (Junaedi dkk., 2006; Gawronska \& Golisz, 2006) and a low level of water availability (Pedrol et al., 2006).

Allelopathy is defined as the direct or indirect stimulatory or inhibitory effects of one plant on other plants around it through release of secondary metabolits are referred to as allelochemicals that escape into the environment, however most of the observations showed allelopathy inhibiting effect on the target organisms (Weir et al., 2004; Gniazdowska \& Bogatek, 2005; Narwal \& Sampietro, 2009).

Several different biotic and abiotic stresses increase the activity of the Phenylalanine ammonia-lyase (PAL) enzyme which catalyses the formation of secondary metabolites(Khan et al., 2011) for adaptation to changes in the environment, and to overcome environmental stresses (Edreva et al., 2008). All secondary metabolites characteristically show allelochemical activity, but phenolic and terpenoids are two of the main groups of compounds which are involved in allelopathy (Inderjid \& Duke, 2003). Phenol is produced in large quantities by plants and its principal role is allelochemical (Narwal \& Sampietro, 2009). The phenolic compounds which are most common in allelopathy are derivates of cinnamic acid, benzoic acid, coumaric acid, tannin, polyphenol complex and certain types of flavonoids ( Einhellig, 2004). Single allelochemical compound often displays several phytotoxic effects, amongst which it is hard to distinguish between primary and secondary effects, to the point where it is difficult to understand exactly the inhibiting mechanism (Zhou \& Yu, 2006). Despite this, according to (Weir et al., 2004; Singh et al., 2009), the most important phytotoxic allelochemical mechanism is through the increased production of Reactive Oxygen Species (ROS), which cause oxidative stress. The disturbance to the plasma membrane causes the initial and basic allelochemical effect, and proceeds to affect several different cell functions, causing general disturbance to cells, and finally leading to the destruction and death of cells (weir et al., 2004; Einhellig, 2004). Weeds also exert allelopathic effects on crop seed germination and growth by releasing water-soluble compounds into the soil (Tanveer et al., 2010).

This experiment was conducted in order to study the allelopathic effect of purple nutsedge tuber aqueous extract on seed germination and initial growth of soybean.

\section{MATERIAL AND METHOD}

\section{Collection of plant material}

Purple nutsedge tubers were collected randomly from the field in Babadan, Semarang, Central of Java. Soybean (Glycine max L. cv. Grobogan) seeds were obtained from Balai Penelitian Kacang-Kacangan dan Umbi-Umbian (BALITKABI) in Malang, Indonesia

Preparation of extract of purple nutsedge tubers.

Extract of purple nutsedge tuber concentration of $100 \%$ was prepared by crushing fresh tubers and immersing them in distilled water for 24 hours with a 1:1 weight/volume ratio, filtered three times using filter paper, then diluted with distilled water to achieve extract concentrations of 5, 10, 15, 20 and $25 \%$.

\section{Experimental setup}

The experiment was conducted in the Plant Structure and Function Laboratory, Biology Department, Faculty of Science and Mathematics, Diponegoro University. The experiment was performed with five different concentrations of extract $(5,10,15,20,25 \%)$ and a control $(0 \%)$. Before the germination test, the seeds of soybean were selected, chosen for uniform size and then sterilised by dipping in a $1 \%$ solution of hypochlorite for 20 minutes (Siddiqui et al., 2009). For each treatment, ten soybean seeds were placed in petri dishes on 3 layers of filter paper and $5 \mathrm{ml}$ of extract or water was added to each dish. Throughout the treatment, the extract or water was topped up at the same volume to prevent the seeds and seedlings from drying out. The observation of 
germinating seeds was conducted every 6 hours for 36 hours. Seeds were considered to have germinated if the radicules had attained a length of $2 \mathrm{~mm}$. The treatment was stopped after 36 hours and the wet weight and the dry weight and the length of germination were measured. The percentage of germination $(\% \mathrm{G})$, the Mean Germination Time (MGT), Germination Index (GI) and Growth Tolerance Index (GTI) were also counted. The counting of the parameters was carried out according the formula used by(Akinci \& Akinci, 2010) as follows :

$\% \mathrm{G}=\mathrm{G} / \mathrm{T} X 100$ 1

Where $\mathrm{G}$ is number of total germinated seeds; $\mathrm{T}$ is number of total seeds in experiment.

$\mathrm{MGT}=\sum \mathrm{GtDt} / \mathrm{G}$ 2

Where Gt is number of total germinated seeds at day $\mathrm{t}$; Dt is day; $\mathrm{G}$ is germinated seeds.

$\mathrm{GI}=\sum(\mathrm{Gt} / \mathrm{Dt})$ 3

Where Gt is germination rate at day $t, D t$ is day $t$.

$\mathrm{GTI}=\frac{1}{\mathrm{n}} \sum_{\mathrm{i}=1}^{\mathrm{n}} \frac{\mathrm{PCri}}{\mathrm{PCi}}$ X $100 \% \ldots . .4$

Where PCri is the established value of the respective i-th parameter of the allelopathy applied palnts; Pci is the established value of the respective $i$-th parameter of the control plants; $n$ is the number of the used morphological parameter.

Statistical analysis

Seed germination and initial growth seedling experiments utilized a completely randomized design at each stage of the research, with five replications. Collected data were analysed by using analysis of variants (ANOVA) and the significant difference between mean treatments were compared by Duncan's Multiple Range test at $\mathrm{p}<0,05$.

\section{RESULT AND DISCUSSIONS}

The allelopathic effect of purple nutsedge tuber extracts on the germination and initial growth of soybeans is show in Table 1, Table 2, Figure 1 and Figur 2. It is showed that soybeans deteriorate after purple nutsedge tuber extract treatment. This is indicated by decreased growth tolerance index (GTI), germination index (GI), seedling wet weight, seedling dry weight and seedling length and increased mean germination time (MGT). However, the treatment had no effect on percentage of germination.

Extract of purple nutsedge tuber caused a decrease in GI. Treatment of the extract at a concentration of $5 \%$ was significantly decreased GI compared with control. It is shows a trend that the higher the concentration of the extract, the greater the decrease of the GI value, while treatment at concentrations of 10,15, 20 and $25 \%$ showed no significant differences. GI is directly related to MGT and \%G (Khan et al., 2011). However, the result of this experiment shows that the effect of purple nutsedge tuber extract does not significantly affect on the $\% \mathrm{G}$ value of soybean seeds. This is indicated by the fact that soybean seeds still germinated with a treatment of purple nutsedge tuber extract up to a concentration of $25 \%$ and not significantly different from controls. However, treatment with purple nutsedge tuber extract significantly increased the value of MGT. MGT expresses the speed of the process of seed germination, so the higher this value, the longer the time needed for the seeds to germinate. This was shown in the result of this experiment, which indicated that beginning with a concentration level of $5 \%$, there was already an effect of decrease in the speed of germination, and the higher the concentration, the longer the time needed to begin to germinate (Figur 1). These results are similar to the finding of (Moosavi et al., 2011) that allelopathic effect of aqueous extract of leaf, stem and root of Sorgum bicolor was not significant for germination percentage of Vigna radiata $\mathrm{L}$. and this is differs from the allelopathic effect of Silybum marianum $\mathrm{L}$. which as well as increasing MGT, also decreased the GI and \%G values of Phaseolus vulgaris L., Vigna radiata L, Cicer arientinum L. dan Glycine max L. (Khan et al., 2011). While in another case, the allelopathic effect of Euphorbia helioscopia decreased the \%G of Triticum aestivum L., Cicer arietinum L. dan Lens culinaris Medic. (Tanveer et al., 2010). 
Table 1. Effect of purple nutsedge (Cyperus rotundus L.) tuber extracts on germinations seeds of soybean (Glycine max L. cv. Grobogan)

\begin{tabular}{cccc}
\hline \multirow{2}{*}{$\begin{array}{c}\text { Extract } \\
\text { concentration } \\
(\%)\end{array}$} & \multicolumn{3}{c}{ Mean Parameters } \\
\cline { 2 - 4 } & GI & MGT & \\
\hline 0 & $9,302^{\mathrm{a}}$ & $96,000^{\mathrm{a}}$ & $4,414^{\mathrm{c}}$ \\
\hline 5 & $7,188^{\mathrm{b}}$ & $94,000^{\mathrm{a}}$ & $4,646^{\mathrm{c}}$ \\
\hline 10 & $5,288^{\mathrm{c}}$ & $94,000^{\mathrm{a}}$ & $5,008^{\mathrm{b}}$ \\
\hline 15 & $4,764^{\mathrm{c}}$ & $88,000^{\mathrm{a}}$ & $5,042^{\mathrm{b}}$ \\
\hline 20 & $4,290^{\mathrm{c}}$ & $98.000^{\mathrm{a}}$ & $5,148^{\mathrm{ab}}$ \\
\hline 25 & $4,478^{\mathrm{c}}$ & $88,000^{\mathrm{a}}$ & $5,452^{\mathrm{a}}$
\end{tabular}

GI=Germination index, MGT=mean germination index, $\% \mathrm{G}=\%$ germination. Means in the same columns with the same letter are not significantly different.

Table 2 Effect of. purple nutsedge (Cyperus rotundus L) tuber extracts on initial growth of soybean (Glycine max L. cv. Grobogan) seedling

\begin{tabular}{|c|c|c|c|c|}
\hline \multirow{2}{*}{$\begin{array}{c}\text { Extract } \\
\text { concentr } \\
\text { ation }(\%)\end{array}$} & \multicolumn{4}{|c|}{ Mean Parameters } \\
\hline & GTI & $\begin{array}{c}\text { WW } \\
(\mathrm{g})\end{array}$ & $\begin{array}{c}\text { DW } \\
\text { (g) }\end{array}$ & $\begin{array}{c}\mathrm{L} \\
(\mathrm{cm})\end{array}$ \\
\hline 0 & $100,000^{\mathrm{a}}$ & $3,650^{\mathrm{a}}$ & $4,890^{\mathrm{a}}$ & $4,890^{\mathrm{a}}$ \\
\hline 5 & $80,376^{b}$ & $3,302^{b}$ & $0,866^{\mathrm{b}}$ & $3,380^{\mathrm{b}}$ \\
\hline 10 & $77,006^{\mathrm{cb}}$ & $3,138^{b}$ & $0,826^{\mathrm{b}}$ & $3,318^{b}$ \\
\hline 15 & $71,808^{\mathrm{cd}}$ & $0,856^{\mathrm{c}}$ & $0,856^{\mathrm{b}}$ & $2,622^{\mathrm{c}}$ \\
\hline 20 & $63,730^{\mathrm{d}}$ & $0,708^{\mathrm{c}}$ & $0,818^{\mathrm{b}}$ & $2,296^{\mathrm{c}}$ \\
\hline 25 & $55,308^{\mathrm{e}}$ & $0,708^{\mathrm{c}}$ & $0,700^{b}$ & $1,828^{\mathrm{d}}$ \\
\hline
\end{tabular}

GTI=Growth tolerance index, $\mathrm{WW}=$ wet weight seedling, DW = dry weight seedling, $\mathrm{L}=$ length seedling. Means in the same columns with the same letter are not significantly different.

GTI (Table 2) demonstrate the effect of applied stress factor on plant growth and development. This was calculated using the established values of all morphological parameters [32]. In this experiment, the GTI is based on three values, which are wet weight, dry weight and length of seedling. The result of the experiment shows that treatment with purple nutsedge tuber extract significantly reduced the GTI value. The higher the concentration of the extract, the lower the GTI value. This is in accordance with the decrease in wet weight, dry weight and seedling length which form the parameters of early growth of soybean seedling. Figure 2 shows the comparison between seedlings as a result of allelopathic influence.

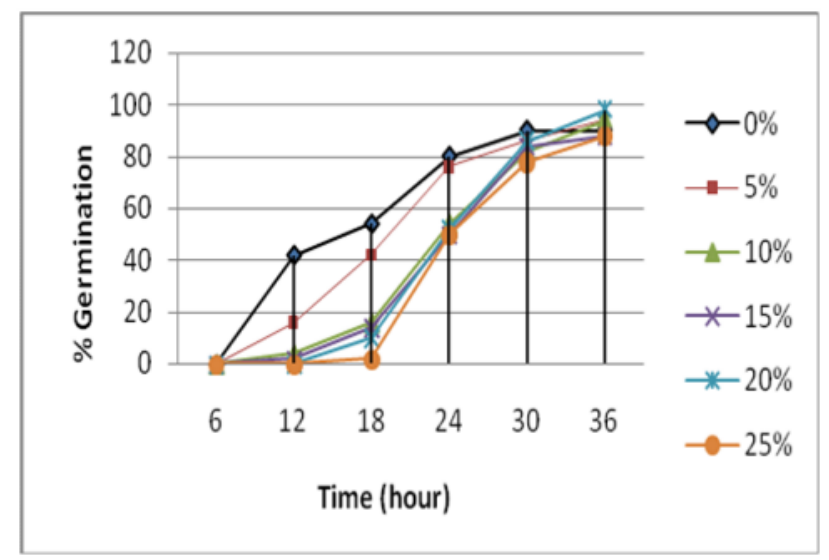

Fig. 1. \% Germination of Glycine . max L. seed which had been treated with various concentrations of Ciperus rotundus L. tubers extract (L-R: $0,5,10,15,20,25 \%)$ at $6,12,18,24,30$ and 36 hour.s treatment..

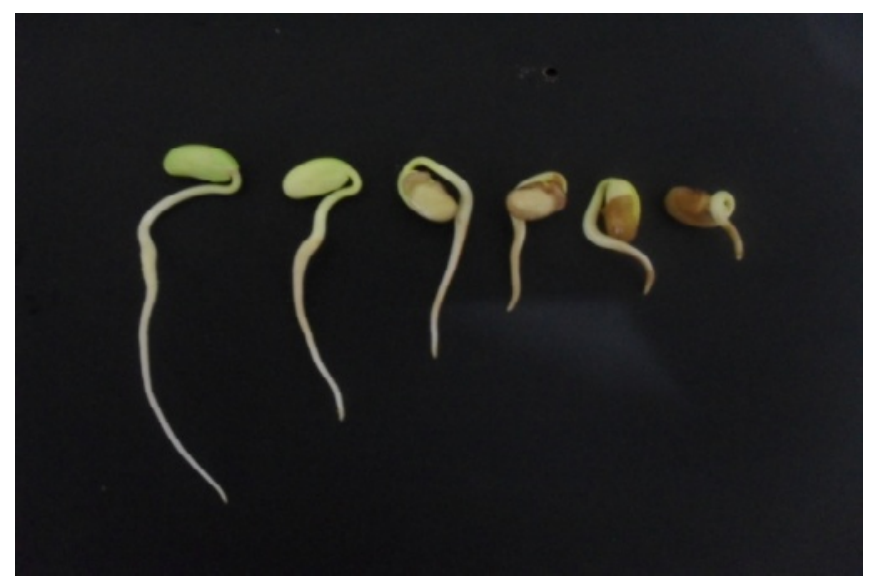

Fig 2. Seedling of soybean (Glycine max L. cv. Grobogan) which had been treated with various concentrations of purple nutsedge (Cyperus rotundus L.) tubers extract (L-R: 0, $5,10,15,20,25 \%)$ at 36 hours treatment

Allelopathic effect mainly caused by phenolic compounds, (El Rokiek et al., 2010) reported that the water extract of purple nutsedge tubers contains cafeic acid, ferulic acid, fanilic, acid, hydrobenzoic acid and chlorogenic acid. According to (Weir et al., 2004) and (Khan et al., 2011), increase in ROS production among target plants caused by allelochemical induction is the 
main mechanism of allelochemical toxicity which then causes oxidative stress. At the same time, disturbance to the plasma membrane is the primary and most basic allelochemical effect (Einhellig, 2004). Allelochemicals also cause decrease in activity of the $\mathrm{H}^{+}$ATPase enzyme, degradation of the sulfhydryl protein group, decrease in transmembrane electrochemical potency, and depolarisation of membranes which causes change in membrane structure and change in non-specific anion and cathion efflux (Gniazdowska \& Bogatek, 2005; Hejl \& Koster, 2004). The occurrence of increase in lipid peroxidation and loss of membrane integrity cause electrolyte leakage (Bogatek et al., 2006), inhibition of absorption of certain ions (Chakraverty et al., 2005), disturbance to synthesis of pigments (Singh et al., 2009; Sodaeizadeh et al., 2009); Batish et al., 2007; Yang et al., 2004), and effects on mitochondrial function which cause disturbance to respiratory function (Einhellig, 2004; Gniazdowska \& Bogatek, 2005) as well as disturbance of hormone activity (Einhellig, 2004; Moosavi et al., 2011).

\section{REFERENCES}

Abenavoli, M.R., A. Lupini, S.Oliva and A. Sorgona. 2010. Allelochemical Effects on Nitrate Uptake and Plasma Membrane H+ATPase Activity in Maize Seedling. Biologia Plantarum 54(1):149-153.

Akinci I. E. and S. Akinci. 2010. Effect of Cromium Toxicity on Germination and Early Seddling Growth in Melon (Cucumis melo L.). African Journal of Biotechnology 9(29) : 4589-4594.

Anonymous. 2009. Petunjuk Teknis Pengelolaan Tanaman dan Sumberdaya Terpadu (PTT) Kedelai. Balai Pengkajian Teknologi Pertanian (BPTP). Jawa Barat.

Anonymous, 2012. Pedoman Teknis Pengendalian Produksi Tanaman Kedelai. Direktorat Jendral Tanaman Pangan. Kementrian Pertanian. Republik Indonesia.

Atman. 2006). Pengelolaan Tanaman Kedelai di Lahan Kering Asam. Jurnal Ilmiah Tambua $\mathrm{V}(3): 281$.

Batish, D.R., K. Lavanya, H.P. Singh and R.K. Kohli. 2007. Phenolic Allelochemicals
Release by Chenopodium murale Affect The Growth, Nodulation and Macromolecule Content in Chickpea and Pea. Plant growth 51:119-128.

Bogatek, R., A. Gniazdowska, W. Zakrewska, K. Orscz and S.W. Garwronski. 2006. Allelopathic Effect of Sunflower Extract on Mustard Seed Germination and Seedling Growth. Biologia Plantarum 50 (1): 156158.

Chakraverty, S., K. Sharma, S. Kumar, N.K. Sand and P.B. Rao. 2005. Effects of Three Weed Extracts on Nutrient Uptake in Different Varieties of Wheat Through Radio-tracer Technique and Autoradiography. Bulletin of the National Institute of Ecology 15:171180.

Edreva, A., V.Velikova, T. Tsonev, S. Dagnon, A. Gurel, I. Aktas and E. Gesheva (2008). Stress-Protective Role of Secundary Metabolites : Diversity of Fuction and Mechanisms. Gen.Appi.Plant Physiology 34(1-2) : 67-78.

Einhellig, F.A. 2004. Mode of Allelochemical Action of Phenolic Compounds. Dalam Macias F.A. et al (eds.) : Allelopathy : Chemistry and Mode of Action of Allelochemicals. CRC Press, London.

El-Rokiek, K., S.A.S. El-Din and F.A.A. Sharara. 2010. Allelopathic Behavior of Cyperus rutundus L. on Both Chorchorus olitorius (Broad leaved weed) and Echinochloa crusgalli (Grassy weed) Associated with Soybean. Journal of Plant protection Research 50(3):274-279.

Gawronska H. \& A. Golisz. 2006. Allelopathy and biotic Stresses. In : Allelopathy : A Physiological Proccess with Ecological Implication (eds.) M.J. Reigosa, N. Pedrol and L. Gondzales. Springer. Netherlands. Pp. 211-227.

Gniazdowska, A. and R. Bogatek 2005. Allelopathic Interaction Between Plants : Multi Site Action of Allelochemicals. Acta Plantarum 27 (3B):395-407.

Hejl A.M and K.L Koster 2004. Juglone Disrupts Root Plasma Membrane H+-ATPase Activity and Impairs Water Uptake, Root Respiration and Growth in Soybean 
(Glycine max) and Corn (Zea mays). Journal of Chemical Ecology 5(2):453-471.

Inderjit and S.O. Duke. 2003. Ecophysiological Aspects of Allelopathy. Planta 217: 529539

Junaedi, A., M. A. Chozin and K. H. Kim. 2006. Perkembangan Tekini Alelopati. Hayati. 13 (2) :79-84.

Kavitha, D., J. Prabhakaran, K. Arumugam. 2012. Phytotoxic Effect of Purple nutsedge (Cyperus rotundus L.) on Germination and Growth of Finger millet (Eleusine coracona Gaertn.). International Journal of Research in Pharmaceutical and Biomedical Sciences 3(2):615-619.

Kohli, R.K., D.R. Batish and H.P. Singh. 2006. Allelopathic Interaction in Agroecosystems. In : Reigosa MJ, N.Pedrol and L. Gonzales (eds.) : Allelopathy : A Physiological Preocess with Ecological Implicartion. Springaer. Netherlands.

Khan, T.A., M. Mazid and F. Mohammad. 2011. Status of Secundary Plant Products under Stress : an Overview. Journal of Stress Physiology \& Biochemistry 7(2):75-98.

Khan R., M. A. Khan, W. M. Waqas, A. M. Khan, Z. Hussain, A. Khan and M. A. Raza 2011. Allelopathic Potential of Silybum marianum L. Against The Seed Germination of Edible Legumes. Park. J Weed Sci. Res. 17(3) : 293-302.

Moosavi A., R. Tavakkol Afshari, A. Asadi and M. H. Gharineh. 20011. Allelopathyc Effects of Aqueous Extract of Leaf Stem and ROOT of Sorgum bicolor on Seed Germination and Seedling Growth of Vigna radiate L. Not. Sci. Biol. 3(2) : 114-118

Morvillo C.M., E.B. de la Fuente, A. Gil, M.A. Martinez-Ghersa and J.I. Gonzalez-Andujar. 2011. Competitive and Allelopathic Interference between Soybean Crop and Annual Wormwood (Artemesia annua L.) under Field Conditions. Europ.J. Agronomy 34(4):211-221.

Narwal, S.S. and D.A. Sampietro 2009. Allelopathy and Allelochemicals, Dalam : Sampietro D.A et al. (eds). Isolation, Identification and Characterization of
Allelochemicals/Natural Products. Science Publishers, Plymouth.

Partohardjono, S. 2005. Upaya peningkatan produksi kedelai melalui perbaikan teknologi budidaya. Dalam Partohardjono, dkk. (penyunting). Analisa dan Opsi Kebijakan Penelitian dan Pengembangan Tanaman Pangan. Monograf No.1 2005 Puslibang Bogor : 132-147.

Pedrol, M..N., I. Gomzales and M.J. Reigosa. (2006). Allelopathy and Abiotic Stress. Dlm Reigosa MJ, N.Pedrol and L. Gonzales (eds.) : Allelopathy : A Physiological Preocess with Ecological Implicartion. Springaer. Netherlands

Qasem, J.R. and C.L. Foy 2001. Weed Allelopathy : Its Ecological Impacts and Future Prospects. Journal of Crop Production 4(2):43-119.

Ratnayaka H.H., W.T. Mollin and T.M.Sterling 2003. Phyiological and Antioxidan Responses of cotton and spurred anoda under interference and mild drought. Journal of Experimental Botany 54(391): 2293-2305.

Singh, N.B., D. Singh and A. Singh 2009. Modification of Physiological responses of Water Stressed Zea mays Seedling by Leachate of Nicotiana plumbagiflolia. General And Applied Plant Physiology 35(1-2):51-63.

Siddiqui S., S. Bhardwaj, S. S. Khan, M. K. Meghvanshi. 2009. Allelopathic Effect of Different Concentration of Water Extract of Prosopsis juliflor Leaf on Seed Germination and Radicle Lengh of Wheat (Triticum aestivum Var-Lok-1). American-Euraia Journal of Sientific Research 4 (2) : 81-84.

Singh, N.B., D. Singh and A. Singh. 2009. Modification of Physiological responses of Water Stressed Zea mays Seedling by Leachate of Nicotiana plumbagiflolia. General And Applied Plant Physiology 35(1-2):51-63.

Sodaeizadeh H., M. Rafleiolhossaini, J. Havlik and V. Damme. 2009. Allelopathic Activity of Different Plant Parts of Peganum harmala L. and Identification of Their Growth 
Inhibitors Subtances. Plant Growth Regul. 59 : 227-236.

Tanveer A., A. Rehman, M. M Javaid, R. N. Abbas, M. Sibtain, A. U. Ahmad, M. S. Ibin-I-Zamir, K.M. Chaudhary and A. Aziz. 2010. Allelopathic Potential of Euphorbia helioscopia L. against Wheat (Triticum aestivum L.), Chicpea (Cicer arietinum L.) and Lentil (Lens cularis Medic). Turk J Agric For 34 : 75-81.

Weir, T.L., S.W. Park and J.M. Vivanco. 2004. Biochemicals and Physiolocical Mechanisms Mediated by Allelochemicals.
Current Opinion in Plant Biology 7:472479.

Yang, C.M., I.F.Chang, S.J. Lin and C.H. Chou. 2004. Effect of Three Allelopathic Phenolics on Chorophyll Acumulation of Rice (Oryza sativa) Seedlings : II. Stimulation of Consumption - Orientation. Bot. Bull. Acad. Sin. 45: 119-125.

Zhou Y.H. and J.Q.Yu. 2006. Allelochemicals and Photosynthesis. In : Reigosa MJ, N.Pedrol and L. Gonzales (eds.) : Allelopathy : A Physiological Preocess with Ecological Implicartion. Springaer. Netherlands. 